\title{
Deriva e exílio sexuais: sobre Stella Manhattan, de Silviano Santiago
}

Carlos Henrique Lucas Lima ${ }^{1}$

Marcio Caetano ${ }^{2}$

\begin{abstract}
Nuestra tarea es hacer cosas, pero ¿qué cosas?, ¿hacer qué?, ¿queda algo por hacer?, ¿no lo hemos conseguido todo ya?, ¿no nos podemos casar y operar?, ¿queda un porvenir de discurso y reivindicación por explorar?
\end{abstract}

Paco Vidarte

O romance Stella Manhattan põe a descoberto o interdito da homossexualidade, demonstrando que a sociedade regula o político e o sexual por meio da exclusão. Nessa narrativa, a personagem protagonista Eduardo Costa e Silva/Stella Manhattan, brasileiro homossexual (ou homossexual brasileiro), é enviado compulsoriamente a Nova Iorque, no que aqui denominamos "exílio" devido a sua sexualidade não desejada, verdadeira excrescência e abjeção para sua família. Mas não só para ela, como, por extensão, para seu país - daí a necessidade de exclusão da "família nacional", ${ }^{3}$ em que, após uma série de acontecimentos que remetem à história recente brasileira em torno da ditadura militar, vem a desaparecer sob o cinzento céu de Nova Iorque.

Stella Manhattan, além disso, aposta na deriva sexual como ferramenta-chave no processo que pretende solapar a hegemonia da heteronormatividade e de suas insidiosas e persistentes artimanhas. Queremos chamar a atenção para o intercâmbio proposital que fazemos entre os termos heterossexualidade compulsória e heteronormatividade. A partir da década de 1960, sobretudo devido aos chamados "movimentos de liberação sexual", tanto de visada feminista quanto a Revolta de Stonewall, parece-nos que a heterossexualidade deixou de ser compulsória

\footnotetext{
${ }^{1}$ Doutor em cultura e sociedade e professor da Universidade Federal do Oeste da Bahia (UFOB), Barreiras, BA, Brasil. Dorcid.org/0000-0001-8771-9349. E-mail: prof.chlucaslima@ gmail.com

${ }^{2}$ Doutor em educação e professor da Universidade Federal do Rio Grande (FURG), Rio Grande, RS, Brasil. Dorcid.org/0000-0002-4128-8229. E-mail: mrvcaetano@gmail.com

${ }^{3}$ Como se verá ao longo deste artigo, a categoria da deriva sexual aqui proposta se refere tanto ao envio compulsório de Eduardo Costa e Silva para o exterior quanto, ao mesmo tempo, de sua expulsão da "família nacional". O exílio, então, é duplo e poderosamente violento.
} 
- veja-se, por exemplo, a proliferação das paradas e marchas de orgulho de lésbicas, gays, bissexuais, travestis, transexuais e intersexuais ou toda a produção cultural e comercial, como filmes, livros, moda etc. dedicada ao público homossexual e trans (travestis e transexual) com poder aquisitivo -, passando a exercer sua hegemonia de maneiras renovadas a partir de um complexo empreendimento - que pretende produzir corpos straigh ${ }^{4}$ conhecido como heteronormatividade. Nesse sentido, mesmo não sendo a heterossexualidade uma imposição das sociedades contemporâneas - e pensamos quase que exclusivamente nas sociedades ocidentais - torna-se ela uma base transversal de dispositivos que regulam e produzem tanto sujeitos heterossexuais quanto sujeitos homo e trans.

Junto com Silviano Santiago, é possível afirmar, ainda, que Stella Manhattan oferece um modelo que não é modelo, mas, portanto, um "contramodelo", bem ao gosto da articulação pós-estruturalista, à opressão e consequente exclusão de homossexuais e trans que não aceitam adequarse ao sistema sociocultural gestado pelo sujeito hegemônico do ocidente: o devir enquanto potencialidade política, enquanto liminaridade.

Esse movimento, o do devir ou deriva, além de se constituir, segundo defendemos, em um poderoso estratagema contra as ciladas da heteronormatividade, promoveria a incerteza e a indecidibilidade (Posso, 2009) no lugar do embate e do confronto aberto, o que, talvez, seja mais eficaz, já que deixaria o "inimigo" - a exclusão homófoba - sem saber como proceder.

\section{A liminaridade das identidades em exílio}

A personagem Eduardo Costa e Silva/Stella Manhattan tem uma existência cindida ou "dobradiça", como o quer o próprio Santiago, movendo-se ora por intermédio de uma identidade que remonta à sua brasilidade - Eduardo, funcionário do consulado brasileiro -, ora por meio de um eu pautado pelo camp - isto é, pelo exagero travesti de Stella Manhattan, epônimo que aponta para o desejo de escarnecer do exílio sexual no qual Eduardo se encontra.

A ideia de "derrisão" da heterossexualidade compulsória tem estreita relação com a performance camp de Stella Manhattan, uma vez que pretende minimizar os danos causados pelo exílio sexual imposto a

\footnotetext{
${ }^{4}$ Heterossexual ou, no extremo, corpos direitos - endireitados.
} 
Eduardo Costa e Silva. O camp, nesse sentido, e a noção de excesso, que lhe é intrínseca, contribuem nesse processo que tem por objetivo escarnecer da ordem sexista presidida pela heterossexualidade. Na passagem a seguir, Stella, deprimida após a noite de "amor" com o garoto de programa Rickie, reflete por meio do narrador:

Sem querer um dia encontrou o remédio certeiro contra as angústias noturnas: lembrou-se de uma música de Dircinha Batista, cantarolou-a, depois de outra de Ângela Maria, idem, e mais tarde outra de Dalva de Oliveira, junte tudo o que é teu, teu amor, teus trapinhos, junte tudo o que é teu e saia do meu caminho, e aí achou graça porque já estava achando graça do pesadelo e da dor que oprimia o seu coração. Já sorria bemhumorado, pensando no seu lado coquete e sedutor de bicha tropical em Nova Iorque (Santiago, 1985, p. 28).

O excerto acima aponta para a tomada de consciência de Stella no sentido de se entender na condição de exilada, de "bicha tropical em Nova Iorque", situação essa similar à vivida por muitos exilados políticos latino-americanos à época em que o romance se passa. Vale dizer que a narrativa inicia com a indicação do ano de 1969, momento emblemático tanto sob o ponto de vista das ditaduras que assolavam a América Latina, notadamente o Brasil - e o recrudescimento do Regime, com a ascensão do general Médici, em 1967 -, quanto pelo advento da Revolta de Stonewall, ocorrida alguns meses antes na cidade de Nova Iorque, que deu início ao que atualmente se nomeia "orgulho gay". Nesse sentido, se há, por um lado, essa tomada de consciência de Stella - esse reconhecer-se brasileira -, por outro lado, há que se destacar que isso se dá no exílio; portanto, a partir do "fora", e sob o signo cosmopolita e revolucionário das bichas da cidade de Nova Iorque.

Said (2003), em Reflexões sobre o exílio e outros ensaios, chama a atenção para o fato de a experiência do exílio articular múltiplas identidades e perspectivas que, antes, no seio da família nacional, não eram consideradas. E esse é o ponto em questão quando destaca a construção do nacional a partir do "fora". Em Stella Manhattan, a protagonista - e o próprio leitor, ao se deparar com a estrutura descontínua do romance - constrói o Brasil, e consequentemente sua nacionalidade, a partir de pontos de vista muito distintos, seja através das canções de Dircinha Batista, Dalva de Oliveira ou Ângela Maria, a "inesquecível Sapoti" (Santiago, 1985, p. 28), seja por meio da ideia de "liberdade/libertinagem" (Santiago, 1985, p. 102) que Marcelo, 
ex-colega de faculdade de Eduardo, elabora para ler a situação na qual o país e os exilados se encontram, além das reflexões dos narradores ao longo do texto. A noção de "libertinagem" para substituir a de "liberdade" evoca a experiência homossexual da protagonista e das demais personagens do romance, e esse traço - a libertinagem sexual presente nas experiências homossexuais dessas personagens - constitui o eixo que as integrará e as reunirá em uma "nacionalidade" que transcende as fronteiras físicas de um país, como se verá mais adiante.

Quando Said (2003, p. 46) afirma que o exílio indica uma poderosa fratura entre o "eu e seu verdadeiro lar", sua referência de origem está bem marcada, coisa que nesse romance não se verifica, posto que o rompimento com a família, que não deixa de ser profundo, traumático, tem suas motivações na sexualidade não desejada de Eduardo Costa e Silva. Mesmo que ao longo da narrativa Eduardo expresse seu desejo de retornar ao lar, à casa dos pais, rapidamente essas aspirações se esvanecem por conta da revelação feita por Vianna, outra personagem do romance, de sua condição ilegítima de filho. E, antes desse episódio, reflete Eduardo: "Me arrancaram da vida deles como se fosse uma casca de ferida. Cabe a mim fazer o mesmo. Chorar mais é que não vou. Nem lamentar. Já era" (Santiago, 1985, p. 43).

Não pretendemos asseverar, com isso, que Said (2003) entende de maneira ontológica e, portanto, estática, o conceito de origem; no entanto, é preciso dizer que essa noção é central para suas reflexões acerca do exílio. Também nos estudos em torno da diáspora em sentido amplo, a origem ocupa lugar de destaque, já que o anseio daqueles que saem do território é, sempre, retornar ao lugar inicial - mesmo que, para muitos, isso seja um sonho distante! Ou que o "lar" já não se apresente mais como outrora. Mas, na narrativa sob análise, entendemos que as fraturas causadas pela rejeição da homossexualidade de Eduardo são tão poderosas e dolorosas que a ideia mesma de origem se desfaz, ensejando a constituição do que poderíamos nomear uma nova gregariedade, ou como afirmamos em outro momento, de uma "ética beesha" (Lima, 2017). Quanto a essa nova gregariedade, vale dizer, fazendo coro com Michel Maffesoli (2007), que ela põe em dificuldades, ao que esse autor chama de "Cidade de Deus", um arquétipo que faz alusão à sociedade perfeita, cujo centro é o judaico-cristianismo. Desse modo, a homossexualidade em Stella Manhattan articula novos laços de cumplicidade e partilha, fundando vínculos e reinventando sociabilidades: 
A diferença entre a bicha e o heterossexual é que este - seja homem seja mulher - já tem estilos de vida codificados, e o processo por assim dizer de amadurecimento nada mais é do que o de assumir um dos estilos já perfeitamente realizados pelas gerações passadas. É por isso, continuava Marcelo, que o heterossexual é tão pouco inventivo quando chega à idade da razão, fala a língua de quase todos, enquanto a bicha atinge a maturidade pelo constante exercício da imaginação em liberdade, inventando cada dia o seu linguajar, que por isso mesmo tem necessariamente de ser pitoresco. A bicha tem de criar um estilo que acaba por ser a maneira como se encaixa sem neurose e com sucesso dentro da comunidade que é obrigatoriamente heterossexual (Santiago, 1985, p. 211-212).

Aqui, a personagem Marcelo, professor universitário e espécie de espião a serviço do comunismo internacional em Nova Iorque, discorre a respeito da busca constante que as bichas realizam em torno de "um estilo próprio", pontuando a "imaginação em liberdade" como característica essencial nesse processo. E é exatamente nesse ponto que são ensejadas novas sociabilidades, ou "socialidades", como deseja Maffesoli (2007, p. 6): "face à anemia existencial suscitada por um corpo social demasiado racionalizado, patriarcal, a cultura homossexual destaca a urgência de uma sociedade empática". A sociedade à qual Maffesoli alude é aquela que Marcelo caracteriza como possuidora de "estilos codificados", normativa, que rotula como diferente e, por isso mesmo, anormal, outras formas de organização e enfrentamento da realidade. E essa realidade, como afirma Marcelo, é "obrigatoriamente heterossexual", quer dizer, é regida pela heterossexualidade compulsória, uma vez que, tendo em vista o contexto histórico do romance, ao homossexual eram indicados apenas lugares de abjeção e/ou subversão, como a ideia de que toda bicha é comunista, por exemplo, apresentada na narrativa.

Outro ponto levantado por Marcelo é a invenção que as bichas fazem do linguajar. A língua, enquanto sistema de signos abriga em si mesma um universo, uma explicação singular para experienciar, ver e entender os sentimentos e as materialidades das coisas do mundo. A eclosão de sexualidades não normativas, nesse sentido, é viabilizada exatamente por esse processo - o linguístico, posto que formula tais possibilidades sexuais, afetivas e sociais. A homossexualidade, nesse caso, é resultado de uma performatividade linguística, e não de uma ontologia ou suposta naturalidade. $\mathrm{O}$ que se sustenta aqui, portanto, passa pelo entendimento 
de que o romance subscreve a compreensão pós-estruturalista de sexualidade, qual seja, que ela "é 'aprendida', ou melhor, é construída, ao longo de toda a vida, de muitos modos, por todos os sujeitos" (Caetano, 2016). Sobre a linguagem criada pelos gueis, comenta Paco Vidarte:

A necessidade de criar tal linguagem responde, como não poderia deixar de ser, à marginalidade, quando não à marginalização, da qual a homossexualidade foi objeto em uma sociedade majoritariamente heterossexual. E essa sociedade, ao longo de sua longa história, só foi capaz de produzir termos pejorativos, irônicos, ofensivos, ridicularizantes, condescendentes ou divertidos, na melhor das hipóteses, para se referir a nós e a nosso modo de viver. Segue-se disso, e isso é um bom sinal, o surgimento de uma linguagem privada capaz de veicular realidades, sentimentos, situações, vivências em primeira pessoa e livre da chacota, do escárnio e do riso que nossa vida parece provocar em certa gente e que se cristaliza em uma multiplicidade de palavras e expressões dolorosas, mas que todo mundo utiliza sem lhes dar maior importância (Vidarte, 1999, p. 44, tradução nossa).

Vidarte confere importância às formas de expressões criadas pelos homossexuais - uma linguagem em "primeira pessoa", como afirma ele amparando-se, principalmente, no entendimento de que tal linguagem torna viável a expressão de experiências a partir do olhar dos próprios homossexuais, sem a mediação ridicularizante e/ou condescendente dos heterossexuais. E aí reside a relevância de homossexuais passarem de objetos e temas a sujeitos e protagonistas do discurso que busca representar e visibilizar as práticas e as sociabilidades gueis - nossa referência é o discurso literário neste momento. Além disso, o autor espanhol, mesmo sem indicar de modo claro em seu texto, fornece-nos elementos para afirmar que, de um sistema social regido majoritariamente pela heteronormatividade, somente podem se derivar perspectivas distorcidas ora zombeteiras, ora violentas - do modo de viver dos e das homossexuais.

Em se tratando ainda da necessidade de homossexuais criarem para si uma linguagem que lhes seja favorável, o Pajubá, língua(gem) de ampla circulação entre as travestis, que, por conta da significativa mobilidade das pessoas trans, teve seu uso disseminado - e muitas das vezes, reapropriado, e esse é um processo intrínseco aos sistemas linguísticos sobretudo por gueis. Considerando-se o crescendo da intolerância, da proliferação da xenofobia e da homofobia, o Pajubá se apresentaria como 
um local a partir do qual seria possível negociar uma nova ética por meio da qual homos e heterossexuais, e outras identidades sexuais possíveis, conviveriam de maneira solidária. Tal entendimento encontra sua base de sustentação, sobretudo, nas considerações que Silviano Santiago faz no ensaio "O homossexual astucioso", texto no qual ele busca maneiras de enfraquecer os discursos beligerantes que tornariam difícil o "diálogo" entre homossexuais e heterossexuais.

Antes de prosseguir, no entanto, queremos retornar à ideia de "libertinagem" como um dos eixos da sociabilidade homossexual, como se disse, e pontuar a referência que tal ideia faz à dissolução das normas, ao desmantelamento dos costumes, esses estrados das sociedades ocidentais racionalizadoras e homófobas. Citamos, mais uma vez, Maffesoli (2007, p. 5-6): “Assim, é no interior das sociedades excessivamente racionalizadoras, sociedades higienizadas, sociedades dedicadas a banir toda ameaça, qualquer que seja, é no interior dessas sociedades que a barbárie retorna. É esse igualmente o sentido da homossocialidade". Desse modo, Maffesoli indica que a homossociabilidade não apenas resiste à racionalização naturalizadora das sociedades higienizadas e, portanto, não "libertinas", como ainda evidencia o risco que essas mesmas sociedades representam à liberdade dos cidadãos, já que é justamente a partir de suas configurações cerceantes que "a barbárie retorna".

Após a descoberta da homossexualidade do filho, o pai de Eduardo o manda para Nova Iorque para trabalhar no consulado brasileiro daquela cidade, alijando-o do convívio familiar e extirpando, segundo sua concepção, a vergonha advinda da sexualidade do filho. Esse procedimento, a exclusão, põe a descoberto o estatuto de coisa abjeta da homossexualidade, tanto na sociedade brasileira, quanto de modo mais ampliado, nas sociedades ocidentais.

Eduardo se sentia então como um saco de batatas que tinha sido atirado num canto da casa pelos pais. Não entendia a maneira radical como se distanciavam dele, desmentindo todas as teorias que eles mesmos the tinham inculcado desde criança sobre os laços de sangue, a união da família. Vejo a intolerância, a punição pelo silêncio e pelo distanciamento. Querem me massacrar, pensa Eduardo, quando se dava conta de que queriam se livrar dele como de um objeto cuja utilidade tinha sido perdida com o uso (Santiago, 1985, p. 25). 
No excerto citado, quando Eduardo percebe que o objetivo dos pais é "se livrar dele como de um objeto" já sem serventia, fica patente que certas sexualidades não encontram lugar na dinâmica social e cultural brasileira. Posso (2009, p. 47) afirma que o homossexual e o comunista são homogeneizados "como o lixo que o corpo social precisa expelir para funcionar". Tem-se, aqui, dessa maneira, a síntese do pensamento de uma sociedade regida pela compulsoriedade heterossexual. A presença de Eduardo na família representa um risco, pois não é produtiva para a "harmônica" estrutura social brasileira. Assim, como um "transbordamento" (Santiago, 1985, p. 73), a homossexualidade de Eduardo não é inteligível sob o ponto de vista de seus pais e de seu país, até o limite mesmo em que não encontra legitimidade dentro da sociedade brasileira, o que implica o afastamento - o exílio - de Eduardo de seu país para a cidade de Nova Iorque. Citamos mais uma passagem do romance:

Lembro de uma frase de João Cabral que diz que a norma foi dada ao homem, ou melhor, foi inventada pelo homem para assegurar a satisfação da necessidade; $O$ poeta quer dizer que o que sai da norma é desperdício de energia, é energia jogada pela janela dos maus resultados ou no lixo das boas intenções. A arte não é e nem pode ser norma, é energia desperdiçada mesmo, é alguma coisa, uma ação por exemplo - não importa agora a questão da qualidade - que a energia humana produz num rompante e que transborda num vômito pelo mundo do trabalho, pelo universo do útil, com a audácia e inépcia de alguém que, ao despejar leite numa xícara para se alimentar de manhã, deixa que a maior parte do líquido se desperdice pela mesa (Santiago, 1985, p. 70, grifo nosso).

$\mathrm{O}$ trecho anterior se refere à seção do romance denominada "Começo: o narrador", em que são apresentados ao/à leitor/a os dois narradores de Stella Manhattan: um, extradiegético, quer dizer, exterior à narrativa; e outro, hipodiegético, ou melhor, metadiegético, localizado no interior dessa narrativa que é exterior à própria diegese. Nessa seção do romance, esses narradores discorrem, entre outros temas, sobre a natureza da arte, e suas afirmações bem podem servir de lentes para melhor ler a problemática da homossexualidade da protagonista.

A primeira parte do excerto é emblemática, uma vez que relaciona "norma" e "necessidade", na esteira do poeta brasileiro João Cabral de Melo Neto, destacando, com isso, o caráter "produtivo" - porquanto reprodutor - 
da normalidade heterossexual e classificando tudo o que excede à norma como "vômito", como coisa desnecessária e, dessa forma, supérflua.

Na parte marcada da citação, em que o narrador deixa patente que a norma é uma invenção do homem, uma vez mais a referência é clara: muito embora a homossexualidade de Eduardo Costa e Silva exceda à norma, apresente-se como uma excrescência, como o resto do processo reprodutor capitalista calcado no patriarcado e na heterossexualidade, esta ainda é uma invenção e, logo, nada tem de natural ou legítimo. Diz Maffesoli (2007, p. 7):

A homossexualidade constitui, mais profundamente, uma declaração de guerra ao esquema substancialista que marcou o Ocidente: o Ser, Deus, O Estado, as instituições, o Indivíduo poderíamos prosseguir, à vontade, com uma lista de substâncias servindo de fundamente a todas as análises dominantes. Queiramos ou não, que sejamos ou não conscientes, a ontologia é o ponto de partida dessas análises.

Também Judith Butler (1998), no artigo "Fundamentos contingentes: o feminismo e a questão do pós-modernismo", chama a atenção, nas pegadas de Foucault e Wittig, para o estatuto de "alegoria política" e "unidade fictícia" do conceito de "sexo", e para o fato de este mesmo conceito, ao contrário de ser uma descrição da materialidade, supostamente prévio ao discurso, apresentar-se enquanto produtor e regulador da "inteligibilidade da materialidade dos corpos" (Butler, 1998, p. 39). Tendo tais formulações teóricas em vista, isto posto, é que logramos ler o romance Stella Manhattan considerando a sexualidade não normativa de Eduardo/Stella como lugar permanentemente aberto, tal qual um signo vazio, passível de ser ressignificado sem aviso prévio.

Contudo, retornando à referência a João Cabral de Melo Neto, citado pelo narrador no fragmento anterior do romance, vale dizer que foi ele um poeta conhecido por refutar o excesso e a sentimentalidade em suas obras, por defender a "economia poética", marcando suas produções pela frieza e pela impessoalidade da imagem da "pedra" (Moraes, 2010). E é emblemático, portanto, que ele seja trazido pelo narrador de Stella Manhattan para comentar as especulações desse mesmo narrador sobre a natureza da arte e sobre as relações da homossexualidade com a normalidade sexual. Essas elucubrações do narrador revelam que seu entendimento tanto da arte quanto da homossexualidade passa necessariamente pelo transbordamento e, na esteira de Bachelard, citado na 
epígrafe desse capítulo - "O Narrador" -, coadunam-se com seu comentário que diz: "A conquista do supérfluo proporciona uma excitação espiritual maior do que a conquista do necessário. O homem é uma criação do desejo e não da necessidade" (Bachelard apud Santiago, 1985, p. 67).

Dessa maneira, a arte e a homossexualidade seriam excessos que invadiriam o "universo do útil", sem a preocupação de ocupar algum lugar no racionalizado mundo burguês heterossexual - cuja lógica, sabe-se, é a reprodução (do capital, humana, enfim, a produtividade). $\mathrm{O}$ narrador provoca o leitor e diz que não importa a questão da qualidade da obra, sendo relevante, tão somente, a insolência da arte desaguando pelo "mundo do trabalho", "com a audácia e inépcia de alguém que, ao despejar leite numa xícara para se alimentar de manhã, deixa que a maior parte do líquido se desperdice pela mesa" (Santiago, 1985, p. 70). E essa provocação ao leitor tem, na citação a João Cabral, seu ponto alto, já que o "poeta da pedra" albergava a pretensão de orientar inclusive a leitura de seus poemas, cuidando para que o leitor tivesse acesso apenas ao necessário, e daí a imagem do engenheiro, com toda a exatidão que ela acarreta, presente na produção de João Cabral.

Esse gesto insolente, escarnecedor, que visa à derrisão da heterossexualidade compulsória, eixo que orienta a leitura que neste trabalho fazemos do romance de Silviano Santiago, procede não somente a minar as bases da ordem heterossexista, como, ainda, a desafiar percepções acerca da arte e da literatura. De maneira mais rigorosa, agora, valeria pontuar que, de fato, o que se coloca sob suspeita é mais a possibilidade de se determinar a natureza do literário a partir de critérios que escapariam a juízos de valores etno, sexual e geograficamente localizados, além de outros marcadores, do que cair na armadilha da indefinição, da cômoda postura que suspende as classificações em nome de um pluralismo democrático.

$\mathrm{Na}$ mente do sujeito que se identifica com os discursos que sustentam e naturalizam a heterossexualidade, via repetição, a necessidade e a norma são consideradas centrais, verdadeiras âncoras que proporcionam estabilidade diante das ondas de modernidade e pós-modernidade que ameaçam solapar seu ordenado mundo. Aníbal, que surge no romance como um intelectual a serviço da ditadura militar, comprometido com a sustentação ideológica de seus pressupostos, auxilia o FBI a extirpar do corpo diplomático brasileiro Vianna, o qual havia maculado tanto as 
forças armadas brasileiras quanto a própria nação, por conta da visibilização pública de sua homossexualidade. Diz a personagem Aníbal:

De fora, continua o professor [Aníbal], o brasileiro só traz atos de rebeldia e até mesmo de vingança para com os mais velhos. Não há respeito pela voz do passado e da experiência. Os brasileiros só importam o que bagunça mais a incipiente cultura que criamos à dura pena (Santiago, 1985, p. 125).

O professor Aníbal traça uma diferença entre as coisas úteis e inúteis que vêm de fora. No extrato anterior, em que ele discute com Marcelo, o vigia da moral brasileira deixa claro que aquilo que os "mais velhos" construíram - ele se refere à cultura brasileira, declinada, evidentemente, no singular - precisa ser protegido das hordas comunistas e homossexuais, cujos referentes, entende ele, estão localizados em um "fora", seja nos Estados Unidos seja em Cuba. Aníbal, baseado em sua visão estereotipada de cultura, defende que nós, brasileiros, apenas admiremos os americanos em vez de tentarmos imitá-los, já que não teríamos "condições culturais" (Santiago, 1985, p. 123) nem mesmo para tal. Entretanto, o ensaísta Silviano Santiago (2000, p. 16) entra em cena mais uma vez, quando diz que:

A maior contribuição da América Latina para a cultura ocidental vem da destruição sistemática dos conceitos de unidade e de pureza: estes dois conceitos perdem o contorno exato de seu significado, perdem seu peso esmagador, seu sinal de superioridade cultural, à medida que o trabalho de contaminação dos latino-americanos se afirma, se mostra mais e mais eficaz.

A afirmação de Santiago tem por intenção valorizar o trabalho dos artistas latino-americanos que, durante muito tempo, tiveram suas produções consideradas meras cópias, sombras do que na Europa se criava. Sob uma nova perspectiva, Santiago busca ler esses trabalhos por outra mirada, tomando a intervenção - e não só a artística, mas a migração, quer dizer, a própria presença dos latinos nos chamados países desenvolvidos latino-americana na cultura ocidental como desestabilização do ideário de pureza e unidade atribuídos a ela. Assim, o que Aníbal não entende é que não há essência, mas constructos, cujos objetivos são preservar a hegemonia da visão de mundo sexual e etnicamente centrada.

E, na passagem a seguir, Aníbal, de maneira correspondente àquela com a qual o narrador apresenta sua ideia de arte, comenta as gravuras de Albers, que decoram seu apartamento: 
Escolha da minha mulher, ou do decorador seu amigo. Por mim, teria as paredes brancas. Acostumei-me às letras impressas, ao contraste das palavras pretas no papel branco e ver as cores me incomoda. Quanto mais viva a cor, mais distrai a atenção, mais induz ao devaneio abstrato (Santiago, 1985, p. 126).

Aqui, mais uma vez, nega-se o devaneio, o transbordamento gerado pela transgressão à norma, às regras que coordenam e regulam a sexualidade e a produção artística. Logo após a fala de Aníbal, Marcelo pensa: "Nada de abstrações. O poder é concreto e palavroso" (Santiago, 1985, p. 126), justificando para si mesmo os duros comentários de Aníbal. Entretanto, ainda sobre as gravuras de Albers comentadas por Marcelo, seguindo os passos de Posso (2009, p. 54), é possível afirmar que elas "transcendem a fixidez ontológica indulgentemente", dilatando as rédeas tanto sociais quanto diegéticas que tentam fixar, fechar e ontologizar os discursos sobre a sexualidade e a literatura.

Gosto de Albers. Me lembra coisas de Lygia Clark. Só que, na sua série dos "Bichos", Lygia foi mais longe, misturou a precisão geométrica de Albers com a sensualidade orgânica das bonecas de Bellmer. Albers ficou sempre nos jogos tridimensionais dentro da superfície bidimensional. Lygia descobriu a dobradiça que deixa as superficies planas se movimentarem com a ajuda das mãos do espectador. Os olhos veem depois para apreciar a combinação que foi conseguida. Que cada um conseguiu (Santiago, 1985, p. 127, grifo nosso).

Essa passagem é uma pista que Santiago nos deixa para melhor ler Stella Manhattan: a indecidibilidade, a liminaridade identitária da protagonista, os múltiplos narradores, as micronarrativas que estão no romance, com vistas a estilhaçar a racionalização redutora em torno da narrativa, tornando possíveis inúmeras interpretações, conforme a manipulação das dobradiças pelo leitor/leitora.

Por um lado, o exílio como acontecimento, e, por outro, a abjeção como procedimento narrativo, finalmente, estão estreitamente relacionados no romance porquanto visam, ambos, negar a identidade e a dignidade da protagonista, arrancando-a do território e instaurando o entrelugar como condição existencial de Eduardo/Stella. Nesse sentido, a deriva sexual e sua potencialidade de desconstruir os discursos que abjetizam a homossexualidade e de desterritorializar a heterossexualidade (Preciado, 2011) revelam-se centrais na análise e chave de leitura a partir da qual é 
possível tomar Stella Manhattan como uma narrativa que promove o devir, inviabilizando uma interpretação binomial opressiva (Posso, 2009) e enfraquecendo discursos heterossexistas. Essa interpretação de Stella Manhattan encontra apoio em Karl Posso, uma vez que esse crítico percebe que a "incerteza do desaparecimento incapacita a viabilidade dos discursos opressivos ou da abjeção" (Posso, 2009, p. 65). Assim, nem é possível afirmar que a protagonista foi assassinada/sequestrada nem que ela se matou, por exemplo. A indecidibilidade, portanto, quanto ao paradeiro de Eduardo/Stella indica um desfecho não teleológico, suspendendo "os termos relacionais pelos quais a sociedade ortodoxa, heterossexista, funciona" (Posso, 2009, p. 234).

\section{Deriva Sexual e a desconstrução da heterossexualidade compulsória}

Que forma de imperialismo cultural insidioso legisla para si mesmo sob o signo do universal?

Judith Butler

No trecho a seguir, Paco, a personagem também conhecida como Lacucaracha, afirma que "não gosta de veado [sic] que fez ou faz análise" e considera que eles possuem três defeitos, dos quais, queremos destacar o último, central para os apontamentos iniciais desta seção:

O último defeito é decorrente do que acaba de ser dito. Bicha analisada é tinhosa, tem a mania de querer destrinchar tudo, tintim por tintim, só que destrincha é para mudar, para pensar de maneira diferente e às vezes até contraditória. Cada hora, digo yo, cada minuto mostra uma cara diferente. Parece camaleão. Falta coerência à bicha analisada (Santiago, 1985, p. 213).

Paco/Lacucaracha levanta uma questão fulcral da discussão pósestruturalista, que é a fluidez dos conceitos, a mobilidade epistemológica à qual as teorias e os sistemas de significação estão sujeitos. Essa "mania de querer destrinchar tudo", citada por Paco, é o eixo em torno do qual tanto se torna possível a pesquisa aqui empreendida - uma investigação que aposta no deslocamento de sentidos, na deriva enquanto vereda epistemológica - quanto a leitura da homossexualidade no romance sob análise, já que é justamente a ambiguidade em relação ao desaparecimento da protagonista que inviabiliza os "discursos opressivos ou da abjeção" (Posso, 2009, p. 65). 
Pensamos que a própria condição homossexual potencializaria a curiosidade científica, tão necessária aos projetos e investigações acadêmicas. Partindo desse pressuposto, e considerando as afirmações de Stella Manhattan sobre os estilos codificados dos heterossexuais, é que se torna possível sustentar tal compreensão, já que os homossexuais estariam, continuadamente, tentando reformular-se e abrindo novos caminhos, ou "veredas epistemológicas", na construção de conhecimento. Com isso não queremos dar a entender que os e as homossexuais, como que por herança genética, estariam mais propensos à prática da pesquisa na academia, mas, sim, devido a uma questão contingencial opressora - a heteronormatividade, a reinvenção e a não acomodação estariam na pauta do dia de determinados grupos de homossexuais e isso, portanto, conferiria maior força a essa prática.

Mal sabe Paco que, conforme indica o próprio Eduardo, a suposta falta de coerência e a contrariedade que ele atribui às bichas analisadas é, na verdade, "o que Eduardo chamava de seu estilo" (Santiago, 1985, p. 213), reinventando-se a cada dia, diferentemente dos heterossexuais, os quais, como já antes indicamos, possuem estilos de vida já prontos, codificados. Assim, o que Paco chama de "defeito" ganha no romance uma relevância ímpar, porquanto é o que potencializa a derrisão da heterossexualidade compulsória, tornando inócua sua força para oprimir e tornar abjeta a homossexualidade, exatamente porque as cláusulas binomiais que reduzem as sexualidades e as identidades a critérios estáticos não são aceitas - ou são parcialmente aceitas e depois rejeitadas - pelo "homossexual astucioso".

Quero retomar agora uma das epígrafes utilizadas neste artigo, um trecho de Paco Vidarte (2007, p. 57, tradução nossa):

Falamos sua linguagem perfeitamente [a linguagem dos heterossexuais], eles nos ensinaram desde pequenos; mas somos bilíngues e temos um idioma próprio que, para eles, é incompreensível, bárbaro. Não há nada a ser explicado. Nós nos entendemos. E se traduzimos tudo a cada passo que damos, provavelmente parecerá ridículo, inconsistente, infundado. Não é nossa a tarefa de tradutores. Nossa tarefa é fazer coisas, mas, que coisas? Fazer o quê? Resta algo para fazer? Já não podemos nos casar e operar? Resta um porvir de discurso e reinvindicação por explorar?

Mais uma vez, a questão da linguagem é central na argumentação que aqui fazemos sobre a criação de um estilo próprio de 
homossexuais, algo que é patente no romance; contudo, essa questão é ampliada por Vidarte (2007) ao inserir no debate a ideia de tradução, ou melhor, o quão desnecessário seria que nós, homossexuais, a cada passo que déssemos, indicássemos aos heterossexuais - como que em um movimento tradutório - nossa próxima ação. Em consonância com Vidarte, e também com Deleuze e Guattari (2008), é possível ler o ato final de Stella/Eduardo quando, ao desaparecer sob o céu cinza de Nova Iorque, aposta ela no processo, no devir enquanto contraposição à norma, ao modelo codificado e previsível da heteronormatividade. É, assim, característica central das minorias a imprevisibilidade, a inconstância discursiva e performática que toma a heteronormatividade de surpresa, minando suas bases e dissolvendo a suposta objetividade de seus pressupostos.

Após a descoberta da traição do amigo Marcelo com seu amado Rickie, o garoto de programa branco de olhos azuis - a true wasp -, Eduardo realiza seu ato final e mergulha no devir: "Eduardo põe o fone no gancho de maneira lenta e irrefletida. Não quer mais escutar, não quer mais falar. A ligação não tem mais interesse. Cortá-la como se corta o gás - Eduardo sai deixando a porta do apartamento aberta" (Santiago, 1985, p. 234). É nesse momento que se dá o corte final dos vínculos de Stella com a realidade opressora que a priva tanto do amor quanto da família. São dois os motivos, portanto, que a levam a embarcar na deriva: a traição de seu amigo Marcelo, fato esse que se relaciona com a ideia de "gregariedade" antes referida, e o abandono por parte de sua família, já que Vianna o informa de sua condição ilegítima de filho. Em relação à "gregariedade", o que apontamos não é seu enfraquecimento, mas, sim, sua afirmação, porquanto compreendemos mesmo a traição como parte dos "laços de cumplicidade que foram atados" (Santiago, 1985, p. 41) e, conforme reflete Paco/Lacucaracha:

Cosas de maricones, pensa triste, querendo saber por que son tan malos compañeros las mariquitas. Querem mais é a caveira um do outro. Se dependesse dele, faria um clube, internacional é claro, em que todas se sentiriam como hermanas, onde predominasse $o$ espírito de verdadeira fraternidade. La fraternidad universal. E as bichas más, invejosas, pérfidas, orgulhosas, traiçoeiras, velhacas, maledicentes, desdenhosas, todas seriam punidas, ou então expulsas do clube para o bem da paz no grupo (Santiago, 1985, p. 210-211). 
O devaneio de Paco/Lacucaracha parece-nos mais uma paródia do socialismo internacional - do qual ele é inimigo, pois é um cubano contrário ao Regime de Castro - do que um real sentimento de constituir uma "fraternidade guei", ou, quem sabe, universidal, calcada em qualquer coisa de bom e amável. Os laços de cumplicidade a que se refere Eduardo têm sua indicação clara: as práticas sexuais não normativas dos homossexuais e a violência a que estão sujeitos. Entretanto, assim mesmo, a deriva sexual, tomada como elemento diegético, é uma resposta da homossexualidade frente a uma realidade opressora e perversa. Como afirma Deleuze e Guattari (2008, p. 73): "Se é tão difícil ser 'como' todo mundo, é porque há uma questão de devir".

Por que há tantos devires do homem, mas não um devir homem? É primeiro porque o homem é majoritário por excelência, enquanto que os devires são minoritários, todo o devir é um devir-minoritário. Por maioria nós não entendemos uma quantidade relativa maior, mas a determinação de um estado ou de um padrão em relação ao qual tanto as quantidades maiores quanto as menores serão ditas minoritárias: homem-branco, adulto-macho, etc. Maioria supõe um estado de dominação, não o inverso. Não se trata de saber se há mais mosquitos ou moscas do que homens, mas como o 'homem' constitui no universo um padrão em relação ao qual os homens formam necessariamente (analiticamente) uma maioria. Da mesma forma que a maioria na cidade supõe um direito de voto, e não se estabelece somente entre aqueles que possuem esse direito, mas se exerce sobre aqueles que não o possuem, seja qual for seu número, a maioria no universo supõe já dados o direito ou o poder do homem. [...] É talvez até a situação particular da mulher em relação ao padrãohomem que faz com que todos os devires, sendo minoritários, passem por um devir-mulher (Deleuze e Guattari, 2008, p. 87-88).

Essa citação de Deleuze e Guattari alarga o olhar aqui lançado sobre Stella Manhattan na medida em que apontamos a relação entre o devir e as minorias, chamando a atenção para a posição privilegiada e majoritária do homem branco, ocidental e proprietário - e poderíamos ampliar e dizer heterossexual -, e, ainda, para o fato de que este mesmo homem é quem determina, a partir de um discurso de maioria, o padrão das relações sociais - e seus infinitos desdobramentos - no mundo (Caetano, 2016). É interessante, ainda, destacar a observação de Deleuze e Guattari (2008) no que se refere aos devires passarem, necessariamente, por um 
"devir-mulher", uma vez que, sendo o homem o padrão universal, a mulher - bem como outras minorias - estaria relegada a uma condição secundária e derivativa da primeira, a do homem.

Nesse sentido, Eduardo Costa e Silva/Stella Manhattan passa por um devir, enquanto minoria, inclusive assumindo uma performance que aposta na ambiguidade de gênero, e quem sabe daí uma maior relação com o devir-mulher enunciado por Deleuze e Guattari, negando, com isso, "tudo o que apresenta a si mesmo como razoável, legítimo e portador de uma sanção positiva" (Vidarte, 2007, p. 63, tradução nossa), alicerces esses da heterossexualidade compulsória, controladora e punitiva como que "por direito", conforme indica Deleuze e Guattari (2008), a ser exercido pelo homem.

Nesse sentido, o desaparecimento do objeto legitimador dos discursos que sustentam a compulsoriedade heterossexual - o homossexual - tanto torna inócuas as especulações sobre o destino de Stella Manhattan quanto enfraquecem o poder da heteronormatividade enquanto forma de abjetificar e oprimir os homossexuais. A abjeção do homossexual, que perturba a ordem e a identidade baseadas em um modelo heterossexual, ao ser impossibilitada pela incerteza do desaparecimento de Stella também impede que se perpetuem os discursos beligerantes e oposicionistas que contribuem para a manutenção da situação de margem da homossexualidade. O romance, assim, de maneira suplementar aos escritos do Silviano Santiago ensaísta, a partir das noções de exílio, de deriva sexual e também da aposta na ambiguidade de gênero, consegue fazer tremer os dispositivos de poder da heteronormatividade, tornando seus reclamos inoperantes.

\section{Referências}

BUTLER, Judith (1998). Fundamentos contingentes: o feminismo e a questão do "pósmodernismo". Cadernos Pagu, Campinas, n. 11, p. 11-42. Disponível em: <https://goo.gl/vsiV7K>. Acesso em: 10 jan. 2017.

CAETANO, Marcio (2016). Performatividades reguladas: heteronormatividade, narrativas biográficas e educação. Curitiba: Appris.

DELEUZE, Gilles; GUATTARI, Félix (2008). Mil Platôs: capitalismo e esquizofrenia. São Paulo: 34. 
LIMA, Carlos Henrique Lucas (2017). Linguagens pajubeyras: Re(ex)sistência cultural e subversão da heteronormatividade. Salvador: Devires.

MAFFESOLI, Michel (2007). Homossocialidade: da identidade às identificações. Revista Bagoas, Natal, v. 1, n. 1, p. 1-10, jul./dez.

MORAES, Fabrício Tavares de (2010). A simbologia da pedra na poética de João Cabral de Melo Neto. Mafuá, Florianópolis, ano 8, n. 13, mar.

POSSO, Karl (2009). Artimanhas da sedução: homossexualidade e exílio. Belo Horizonte: Editora da UFMG.

PRECIADO, Beatriz (2011). Multidões queer: notas para uma política dos "anormais". Estudos Feministas, Florianópolis, v. 19, n. 01, p. 11-20, jan./abril.

SAID, Edward (2003). Reflexões sobre o exílio e outros ensaios. São Paulo: Companhia das Letras.

SANTIAGO, Silvano (1985). Stella Manhattan. Rio de Janeiro: Nova Fronteira.

VIDARTE, Paco (1999). Armario: la vida privada del homosexual o el homosexual privado de vida. In: LLAMAS, Ricardo; VIDARTE, Francisco Javier. Homografías. Madrid: Espasa Calpe. p. 44-55. Disponível em: <https://goo.gl/ZJiLRG>. Acesso em: 10 jan. 2017.

VIDARTE, Paco (2007). Ética marica: proclamas libertarias para una militancia LGBTQ. Barcelona-Madrid: Egales.

Recebido em 25 de junho de 2017.

Aprovado em 21 de janeiro de 2018.

\section{resumo/abstract/resumen}

\section{Deriva e exílio sexuais: um ensaio sobre Stella Manhattan, de Silviano Santiago}

Carlos Henrique Lucas Lima

Marcio Caetano

Propomos, neste artigo, a deriva e o exílio sexual como categorias estéticas e políticas manejadas em Stella Manhattan, visando, estrategicamente, provocar o que viemos chamando, a partir de alguns autores e autoras, derrisão da heterossexualidade compulsória. Discutiremos o conceito de deriva sexual com o auxílio de Deleuze e Guattari, e o de exílio, a partir de Said, articulando a 
leitura de tais autores com outros do repertório crítico pós-estruturalista, sobretudo Michel Maffesoli e Judith Butler.

Palavras-chave: Stella Manhattan, deriva, exílio sexual, derrisão da heterossexualidade compulsória.

\section{Sexual drift and exile: an essay on Stella Manhattan by Silviano Santiago}

Carlos Henrique Lucas Lima

Marcio Caetano

This article shows how the novel Stella Manhatten employs the condition of adriftness and sexual exile as aesthetic and political categories to strategically perform what we are calling, using some authors, a derision of compulsory heterosexuality. We will discuss the concept of sexual adriftness with the help of Deleuze and Guattari and the notion of exile using Said. We will read these authors in conjunction with other poststructuralist thinkers, in particular Michel Maffesoli and Judith Butler.

Keywords: Stella Manhattan, adriftness, sexual exile, derision of compulsory heterosexuality.

\section{Deriva y exilio sexual: un ensayo sobre Stella Manhattan, de Silviano Santiago}

Carlos Henrique Lucas Lima

Marcio Caetano

En el presente artículo proponemos la deriva y el exilio sexual como categorías estéticas y políticas manejadas en Stella Manhattan, buscando estratégicamente provocar lo que venimos llamando, a partir de algunos autores y autoras, el derrumbamiento de la heterosexualidad obligatoria. Discutiremos el concepto de deriva sexual con el auxilio de Deleuze y Guattari, y el de exilio, desde Said, articulando la lectura de tales autores con otros del repertorio crítico postestructuralista, sobre todo Michel Maffesoli y Judith Butler.

Palabras-clave: Stella Manhattan, deriva, exilio sexual, destitución de la heterosexualidad compulsoria. 